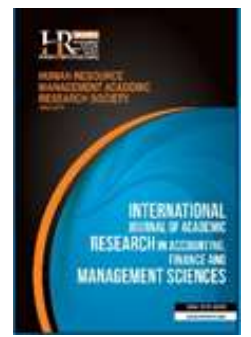

International Journal of Academic Research in Accounting, Finance and Management Sciences

Vol. 9, No.3, July 2019, pp. 83-103

E-ISSN: 2225-8329, P-ISSN: 2308-0337

(C) 2019 HRMARS

www.hrmars.com

To cite this article: Huynh, T. K., Shenai V. (2019). Option Trading Volumes and Their Impact on Stock Prices at Earnings' Announcements: A Study of S\&P100 Stocks in the Post Crisis Era 2010-2017, International Journal of Academic Research in Accounting, Finance and Management Sciences 9(3): 83-103.



\title{
Option Trading Volumes and Their Impact on Stock Prices at Earnings' Announcements: A Study of S \& P100 Stocks in the Post Crisis Era 2010 -
}

\author{
Thuy Khang Huynh ${ }^{1}$, Vijay Shenai ${ }^{2}$ \\ ${ }^{1} M S c$ Finance, University of Westminster, London W1W $7 B Y$, \\ ${ }^{2}$ Phd (Economics), University of Lincoln, Lincoln LN6 7TS, UK, E-mail: kvshenai11@gmail.com (Corresponding author)
}

\begin{abstract}
This study investigates the impact of equity options trading volume on stock price response to earnings announcements, with respect to S\&P 100 listed companies whose options are actively traded on the CBOE market from 2010 to 2017. The data of 90 companies over an eight-year period has been accessed and a quantitative approach is followed in the analysis. In the period after the crisis of 2008, the financial environment has changed substantially: market volatility and interest rates are lower. Panel data regressions are conducted to estimate the impact of options trading volumes, on stock price response to earnings announcements after controlling for size and book to market ratio. This study calculates abnormal returns from stock price response on a risk adjusted basis, unlike previous studies on this topic. The findings are different from studies conducted in the pre-crisis period. Whereas previous research found that call option trading volumes had the most significant effect on stock price reaction to earnings announcements, the current research showed that put option trading volumes have the more significant effect in the postcrisis financial environment. Smaller companies with lower option trading volumes are also found to have larger immediate stock price response to earnings announcements. Again, when the element of earnings surprise is taken into account, the earnings response coefficient (the interactions of the earnings surprise variable on other variables) is found to be significantly relevant for all option trading volumes and highest for put option trading volumes, emphasizing the importance of put options in the environment following the crisis. The results from this study conducted in the post crisis period, add to the literature on the impact of option trading volumes on stock price responses to earnings' announcements and choices of derivative instruments made by market participants in the post crisis era. No such studies studying these effects have been published in the post crisis era.
\end{abstract}

Key words

Put and Call Options, Trading Volume, Stock Prices, Earnings Surprise, Earnings Announcement

Received: 08 July $2019 \quad$ (c) The Authors 2019

Revised: 16 Aug 2019 Published by Human Resource Management Academic Research Society (www.hrmars.com)

Accepted: 18 Aug 2019 This article is published under the Creative Commons Attribution (CC BY 4.0) license. Anyone may Published Online: 28 Aug 2019 reproduce, distribute, translate and create derivative works of this article (for both commercial and non-commercial purposes), subject to full attribution to the original publication and authors. The full terms of this license may be seen at: http://creativecommons.org/licences/by/4.0/legalcode

\section{Introduction}

\subsection{Background}

The stock and derivative markets have considerably expanded and their interactions with other economic factors are given more attention by market makers and financial analysts in recent years. The S\&P 100, a subset of S\&P 500, has reached a market capitalization of approximately US\$15.4 trillion in June 2018 representing the considerable development of the stock market. The component companies of the S\&P 100 are prestigious representatives for their industries, and are chosen to represent sector balance, 
and occupy about $60 \%$ of the S\&P 500's market capitalization (US\$24 trillion, June 18) and 50\% of the market capitalisation of all stocks on the US stock exchanges. The components of S\&P 100 are also companies with active options trading activities and are leaders in the US stock market with exchangelisted options (S\&P 100 Dow Jones Indices LLC, 2018).
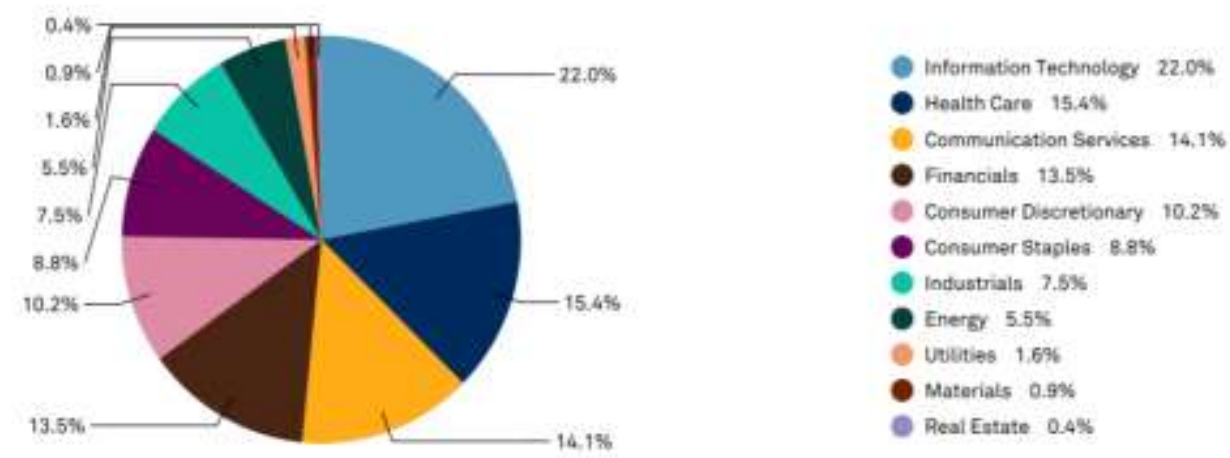

Source: S\&P 100 Dow Jones Indices LLC, (2018)

Figure 1.The sector breaks down of S\&P 100

The sub-prime mortgage phenomenon brought about a major financial crisis, affecting many large stock-markets in the world. The US stock markets dropped to a low in Feb 2009. Many studies therefore differentiate between a pre-crisis and a post crisis period. For the purpose of this research data will be looked at for comparative purposes between 1996-2007 (the pre-crisis period), versus the post crisis period (2010-2017). The S\&P100 index was at 295 in Jan 1996, rising to 790 in November 2000 and falling to 325 in February 2009, and rising again to 1251 in January 2018. The historical performance of the S\&P100 over the period 1996-2017 is given in Figure 2 above. Applying a t-test to the mean returns on the S\&P100 in the pre and post crisis period, the results are as below:

SP100 index values:

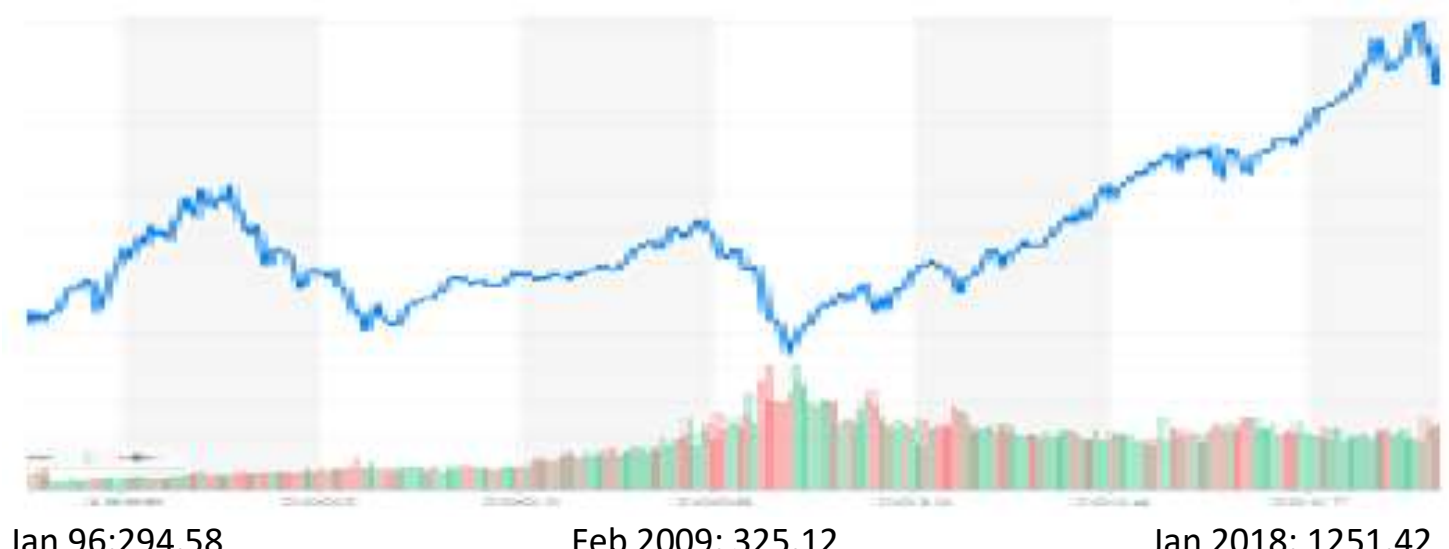

Source: yahoo finance

Figure 2. Historical performance of S\&P 100 index 1996-2018

t-Test: Two-Sample Assuming Unequal Variances
\begin{tabular}{|l|r|r|}
\hline \multicolumn{1}{|c|}{ statistic } & $1996-2007$ & $2010-17$ \\
\hline Mean & 0.0052 & 0.0097 \\
std deviation & 0.0452 & 0.0340 \\
Observations & 144.0000 & 96.0000 \\
\hline t Stat & -0.8740 & \\
P(T<=t) two-tail & 0.3830 & \\
t Critical two-tail & 1.9702 & \\
\hline
\end{tabular}


Figure $3 a$. mean and standard deviation of the S\&P100 in the two periods

In the post crisis period, although mean returns were higher, the statistical test does not show a significant difference with the mean return of the pre-crisis period.

Option markets have grown impressively as there is an informational association between these them and stock markets. According to Stulz (2004), option markets have increased 100 times in size over 30 years to reach a volume of US\$200 trillion. The Chicago Board Options Exchange (CBOE) has the largest trading platforms and markets for options on a range of products, including interest rates, individual stocks and indexes contracts. CBOE provides the options for 22 stock indices and more than 2,000 companies (CBOE, 2014). The interactions between stock and option markets need more attention from financial analysts and researchers around the world because of their critical impact on the economy. In fact, there is just a moderate body of literature on this topic, which is unable to represent a comprehensive understanding of it.

The impact of options listing and option trading volumes on stock price response at earnings announcements is a topic relevant for study as it has implications for all market participants. Options may on the one hand lend stability to financial markets, but on the other hand they may only represent noise trading by speculators without any impact on stock prices. The results of research so far on option listings, trading volumes and earnings announcements on stock price response is covered extensively in the literature review section, and the results are mixed.

In the period after the crisis of 2008 , the financial environment has changed through variables affecting the options market: market volatility and interest rates are lower. The VIX index, compiled by Chicago Board Options Exchange (CBOE), is a measure of the 30-day expected volatility of the U.S. stock market, and is derived from real-time, mid-quote prices of S\&P 500 Index (SPXSM) call and put options. 3m T-bill interest rates are obtained from the website of the Federal Reserve Bank of St Louis (FRED). To demonstrate the changes in the values of the VIX index and three-month T-bill rates in the pre-crisis and post-crisis financial environment are plotted below for the period 1996-2017 in figure 3b and 3c below.

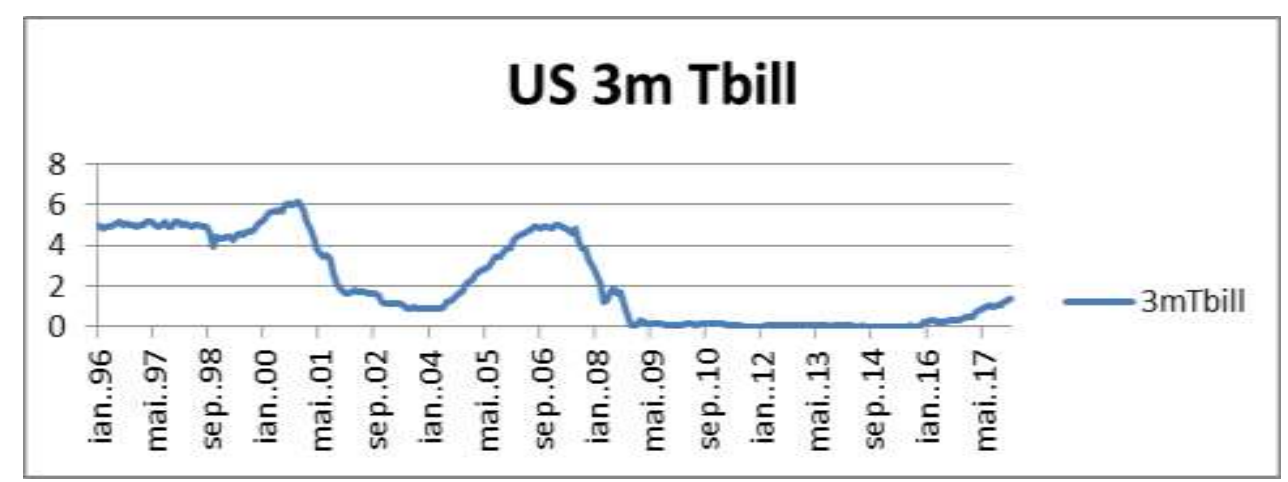

Source: US Department of the Treasury

Figure 3b. US 3-month T-bill values Jan 1996-Jan 2018

The results of a t-test, on the differences in the means in the two periods are given below In Table 1a.

t-Test: Two-Sample Assuming Unequal Variances
\begin{tabular}{|l|r|r|}
\hline Statistic & 3m tbill (19996-2007) & 3m tbill (2010-2017) \\
\hline Mean & 3.7415 & 0.2083 \\
Std deviation & 1.6234 & 0.3032 \\
\hline Observations & 144 & 96 \\
$t$ Stat & 25.4590 & \\
$P(T<=t)$ two-tail & 0.0000 & \\
t Critical two-tail & 1.9751 & \\
\hline
\end{tabular}

Table1a. mean and standard deviation of the 3mtbill in the two periods 


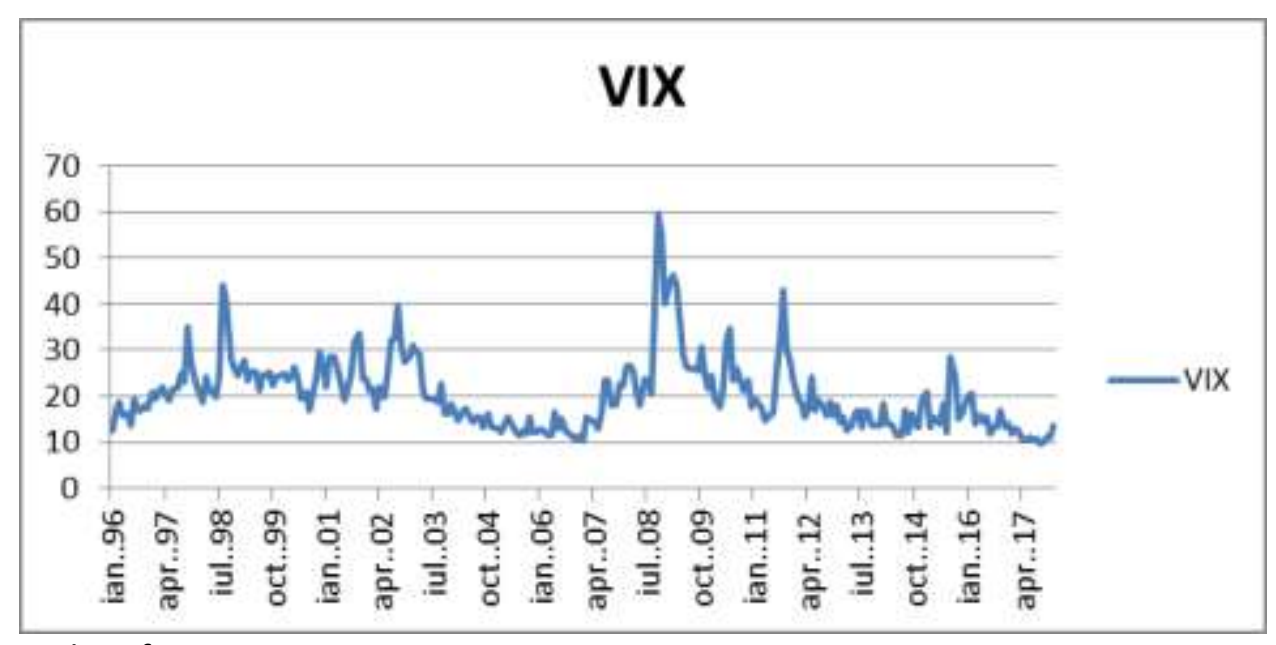

Source: $\mathrm{CBOE}$, yahoo finance

Figure 3c. Values of the VIX index Jan 1996-Jan 2018

The results of a t-test, on the differences in the means in the two periods are given below In Table $1 \mathrm{~b}$ :

t-Test: Two-Sample Assuming Unequal Variances
\begin{tabular}{|l|r|r|}
\hline Statistic & VIX (19996-2007) & VIX (2010-2017) \\
\hline Mean & 20.5490 & 17.3350 \\
\hline Std deviation & 6.4888 & 5.8628 \\
\hline Observations & 144 & 96 \\
t Stat & 3.9852 & \\
\hline P( $(<=t)$ two-tail & 0.0001 & \\
\hline$t$ Critical two-tail & 1.9710 & \\
\hline
\end{tabular}

Table1b. mean and standard deviation of the VIX index in the two periods

In summary, in the post crisis period although the mean return of the S\&P100 is higher than in the pre-crisis period, it is not significantly different from that of the pre-crisis period. However, the mean of the VIX index and the US 3-month T-bill as presented in Tables $1 \mathrm{a}$ and $1 \mathrm{~b}$ above show a significant difference in the two periods (1996-2007) and (2010-2017), with interest rates and volatility significantly lower in the post crisis period as compared to the pre-crisis period. It is thus relevant to explore the impact of option trading volumes on stock price response to earnings announcements in the post crisis period, as compared to the past.

\subsection{Aim of this research}

Although there are a number of studies investigating the relationship between option trading and the movements of stocks prices, there are no studies in the post-crisis period of the effect of option trading volumes and earnings announcements on stock prices. Studies by Muravyev, Pearson and Broussard (2013), Hu (2014), Lin and Lu (2015), are more recent studies and concentrate on the relationship between stock prices volatility and option trading, based upon the data prior to 2010 but these studies did not cover the relationship between option trading volumes and stock price response to earnings announcements. Truong and Corrado (2014) were the first to research the linkage between options' trading volumes and stock price response to earnings announcements, in the pre-crisis period using data from 1996-2007. In the period after the crisis of 2008, market volatility and interest rates are lower, pointing to changes in the financial environment. The aim of this study is to investigate the impact of call, put and total options trading volume on stock prices at earnings' announcements in the post crisis period where the financial environment is different. This research utilizes a large data set of companies listed on the S\&P100 and whose options are actively traded on CBOE market from 2010 to 2017, to comprehensively assess the relationship between options' trading volume and stock price reactions to earnings announcements, after adjusting for size and value ratios. 
In the second part of the research, the interaction of the earnings response coefficient on option trading volumes will also be assessed.

\subsection{Structure of this report}

The rest of this report is structured as follows: in section 2, a comprehensive body of literature relating to option trading, earnings' announcements and the variability of stock prices is reviewed and appraised; section 3 covers the data sources and methodology for this research, the selection of variables, methods of analysis and the basis for construction of the regression model; in section 4 data is descriptively discussed and then statistical tests are conducted and the results are interpreted; in section 5 the findings from this research are discussed and critically appraised by comparing with previous research; finally in section 6, the results from this research are reviewed and limitations and recommendations for further research are made.

\section{Literature review}

Black (1975) implied that options trading is attractive to informed investors because it is less restricted and because of the leverage it offers as compared to stock trading and valuable information is available from options markets to predict the movements of stock prices in the future. Manaster and Rendleman (1982) suggested that the reactions of stock prices to information related to firm valuation are significantly impacted by the option market. Cox and Rubinstein (1985) suggested that informed traders prefer the options market because they can possibly construct the portfolios that eliminate the restrictions applied on short-selling strategies. The speed of stock prices movements' response to information is thus accelerated, and informed traders can effectively utilize their private information to trade efficiently and quickly.

Jennings and Starks (1986) studied the reaction of stock prices to earnings announcements based upon the quarterly earnings announcements of companies and found that the level of stock price response to earnings announcements is determined by the existence of options, and stock prices of firms with option listing reacted faster to earnings announcements than the stock prices of firms without options listings, supporting the hypothesis that the options market plays an important role in distributing the information related to earnings announcements.

Stein (1989) believed that the information obtained from options market and trades creates an unfavourable externality on uninformed traders in the market which consequently affects their ability to analyse stock price movements. Amin and Lee (1997) and Cao, Chen and Griffin (2005) find that informed trading takes place in the options market before earnings and take-over announcement events. Skinner (1990) studied the impact of the informational content of earnings announcement events on the stock price movements and found that companies with listed options had a smaller absolute price response to earnings news smaller earnings response coefficient after an options listing than before the options listing.

Damodaran and Lim (1991) found that the listing of options leads to significantly lower variance in the daily returns or the underlying stocks, price adjustment to new information and that the noise component declines after the listing of options, implying that the speedier price adjustment process is attributed to increased information collection after the listing. However, a paper by Long et al. (1994) on the impact of an initial option listing on the price volatility and trading volume of underlying OTC stocks found no significant changes following option initiation, concluding that option listing does not destabilize the market for the underlying stock. A later study by Mayhew and Mihov (2000) however, found that contrary to previous research, volatility increases with option listing, consistent with the hypothesis that forward-looking exchanges list options in anticipation of increasing volatility.

A study by Peterson (1995) to assess events when stock prices decrease by 10 percent or more found that it is 1.57 percent higher for the companies without option trading as compared to the firms with active option trading, suggesting that option trading stabilizes the movements of stock prices; a conclusion which is supported by an earlier study by Jennings and Stark (1986). However, Mendenhall and Fehrs (1999) revisited earlier research by Skinner (1990) to interpret the effects of options trading on the immediate stock price reaction to earnings announcements, with a larger data sample from 1973 to 1993, using firm's market capitalization to control for size as in the study by Ho (1993). They concluded that an option listing 
increases the value of the stock price response and the earnings response coefficient. Alternative studies by Delong et al. (1990), Vijh (1990), Stefan and Whaley (1992) claimed that options trading is noise trading and not information based, giving rise to the expectation that it has no impact on stock price response to earnings information. Thus in spite of the fact that some studies have successfully shown the significant relationship between option listing and lower stock price variability, there are other studies which conclude that there is not enough clear evidence to confirm the association between them.

Pan and Poteshman (2006) interpreted the impact of option trading volumes on the variation in stock prices in the future, using the put call ratio and found support for the conventional wisdom (TheWall Street Journal) to use the put-call ratio on index options as a contrarian rather than a momentum signal. They demonstrated that the performance of a stock is positively affected by the put-call ratio: stocks with low put-call ratio stocks outperforming stocks with high put-call ratios in the next day and also over the next week.

Kothari and Ball (1991) studying the phenomenon of stock price response to earnings announcements found that abnormal returns were positive for small size firms (smallest decline) and negative for large size firms (largest decline) on announcement day and building up to much higher positive accumulation for smaller firms over a five day period (by about $7 \%$ per annum, taking into account four quarters) as compared to negative cumulative returns over the same period for larger firms. This was ascribed to information availability and uncertainty resolution in the case of small firms and tax provisions for larger firms which were more transparent. A later study by Kothari et al (2006), of aggregate stock price response to earnings information found that stock returns were higher in periods of negative earnings growth compared to periods of higher earnings growth, attributing this to changes in the financial environment, as they found positive correlations between periods of higher earnings and interest rates. Lim (2009) examined the impact of quarterly earnings announcements on 30 stocks in the S\&P 100 Index with the largest market capitalization at the end of 2008, as well as earnings surprise and volatility and found that there appears to be an increase in volatility in the trading period after earnings are announced, but there is no systematic bias that indicates which direction prices will go in that period. The end of 2008 was at the nadir of the crisis period. Other important aspects relevant to earnings' quality are competently covered in Jelodari and Asadi (2016), Anis and Chabchoub (2016), Abdul Karin Al-Shar and Dongfang (2017).

Truong and Corrado (2014) investigate the impact of option trading on stock price response to earnings announcement using size and book-to-market as control variables, for all stocks on the NYSE, ASE and NASDAQ stock exchanges for which data on stock prices, trading volumes, option trading and earnings and earnings estimates are available on the (CRSP), (IBES) and (IvyDBUS) databases, for the period 19962007. Their findings are that higher options trading volumes reduce the immediate stock price response to earnings announcements and the earnings response coefficients, relating this phenomenon more to call options trading volumes than put option trading volumes. The additional implication is that options trading incorporate private information regarding forthcoming announcements. And thereby being information based, options are not redundant trading securities.

More recent studies as Mazouz, Wu and Yin (2015) examined the association between stock and options trading statuses in the market, for stock price events where there was considerable variation, focussing on the impacts of the magnitude of option trading instead of the existence of options, and stock price response to shocks. The main findings of their study were that informed agents are more likely to trade options prior to negative news and stocks ahead of positive news. They also found that optioned stocks overreact to the arrival of negative news but react efficiently to positive news. A study by Gulec (2016) on stocks listed in the Turkish Stock Exchange, found that introduction of options market in the Borsa Istanbul resulted in an increase in the level of their market volatility, contrary to the expectation that the derivatives market has a stabilizing effect on financial markets by providing investors various hedging tools to minimize their risks. Another study by Joshi (2018) investigated the impact of single stock option trading on the volatility of underlying stocks in the Indian market using data of companies listed on National Stock Exchange (NSE) of India and concluded that pre and post listing volatility for large cap, mid cap, and small cap was reversed after the options listing highest volatility is recorded for large cap stocks, followed by mid cap, and lowest for small cap stocks. 
In summary, the impact of option trading on stock price is mixed: while some studies suggest that options trading strategies through better leverage offer an advanced investment platform and have the effect of stabilising the market; other studies present an alternative school of thought that option trading volumes are irrelevant to the volatility of stock prices. Studies on the impact of earnings announcements on stock prices have shown that this has a different effect for small and large firms while on an aggregate basis the response of firms to earnings announcements depends to a large extent on the financial environment. Research also shows that stocks overreact to the arrival of negative news on earnings but react more efficiently to positive news. Finally, the impact of option trading volumes is different for larger, medium and small cap companies, implying that size is an important variable in determining the extent of response of stock prices to option trading volumes. The variations in the findings could also be due to changes in the financial environment over time and particularly in the immediate pre-crisis period (19962007), as compared to the post crisis period (2010-2017). It thus becomes relevant to assess the impact of option trading volumes and surprises in the earnings announcements on stock price changes where the financial environment has changed substantially with lower volatility and lower interest rates than previously. Such studies accounting for the financial environment have not been made in the post crisis period.

\section{Methodology of research}

The aim of this study is to examine the impact of options trading volumes on the immediate stock prices response to earnings announcements of listed companies on S\&P 100 from 2010 to 2017. After extensively reviewing previous research and alternative ways to study this problem, there is sufficient ground to expect that option trading volumes have an effect on stock price response to earnings announcements and therefore a positivist, deductive approach is chosen.

Regression models are firstly run to test the impact of option trading volumes on abnormal returns in stock prices after allowing for size (larger companies are expected to be more transparent through stockmarket pressure) and book-to-market ratios (to test for the effects of value stocks versus growth stocks). In a second run, earnings surprises are additionally taken into account and the interaction between earnings surprises, options trading volumes, size and book-to-market are tested on abnormal returns related to stock price response. In the introduction section, changes in the financial environment in the pre and post crisis period (volatility and interest rates) which affect options markets, were identified and this is to be kept in mind as environmental changes can change the behavioural choice of market participants.

\section{Estimation methods}

\section{Options trading volume}

Options trading volume data is obtained from the official website of CBOE. OPTVOL $L_{i, q}, C A L V O L_{i, q}$, and $P U T V O L_{i, q}$ are the daily average options trading volume, daily average call options trading volume and daily average put option trading volume for stock $i$ in quarter $q$ respectively. The options trading volume of stock $i$ in quarter $q$ is proxied by the number of outstanding shares $i$ with respect to the options contracts traded on CBOE in quarter $q$ (Philbrick and Stephan, 1993).

\section{Stock prices response to earnings announcements}

Truong and Corrado (2014) utilize buy and hold returns and calculate abnormal returns with respect to equally weighted size-decile to which the stock belonged; to represent the stock price response to earning announcements. In this study, the cumulative abnormal return is calculated on a risk adjusted basis as in Ball and Kothari, 1991; Hussin et al., 2010; Syed and Bajwa, 2018. It is calculated by subtracting actual return from the expected returns (MacKinlay, 1997).

$$
A R_{i, t, q}=R_{i, t, q}-E R_{i, t, q}
$$

Where:

$A R_{i, t, q}$ is the abnormal return of stock $i$ on day $t$ relative to the announcement event of quarter $q$ 
$R_{i, t, q}$ is the actual return of stock $i$ on day $t$ relative to the announcement event of quarter $q$

$E R_{i, t, q}$ is the expected return of stock $i$ on day $t$ relative to the announcement event of quarter $q$

The actual return of the stock is calculated from the stock price collected from the Bloomberg terminal. The Capital Asset Pricing Model (CAPM) is the applied to estimate the stock expected return (Investopedia, no date).

$$
\left.E R_{i, t}=R_{f, t}+\beta_{i} R_{m_{i} t}-R_{f, t}\right)
$$

With $R_{f, t}$ is the risk-free rate on day $t$ (3-month US Treasury-bill rate obtained from the official website of U.S Department of the Treasury)

$R_{m, t}$ is the daily market returns on day $t$ (S\&P 100 index obtained from the Bloomberg terminal)

$\beta_{i}$ is the beta of stock $i$.

The market model (Sharpe, 1964) is applied to calculate the beta, which is the slope of the regression analysis of market return and stock return from the whole period of the data sample (2010 to 2017), which illustrates how the stock fluctuates regarding the movements of the market The relation between the market and stock price movements can be illustrated in term of a straight line, which is called the characteristics line (Syed and Bajwa, 2018).

$R_{i, p}=\alpha_{i, p}+\beta_{i, p} R_{m, p}+\varepsilon_{i, p}$

With ${ }^{R_{i, p}}$ is the returns of stock $i$ during time period $p$;

$\alpha_{i, p}$ is the intercept for the characteristics line for stock $i$ during period $p$;

$\beta_{i, p}$ is the slope of the characteristics line for stock $i$ during period $p$;

$R_{m, p}$ is the market return (S\&P 100) during time period $p$;

$\varepsilon_{i, p}$ is the disturbance term of stock $i$ during the time period $p$

The immediate stock price response to earnings announcement is proxied by the cumulative abnormal return in 3 days around the earnings announcement period (CAR from day -1 to day 1 ).

$$
C A R_{i, q}=\sum A R_{i, q_{z}, t} \text { with }{ }^{t=-1,0 \text { and } 1 .}
$$

\section{Earnings surprise}

The earnings surprise variable is proxied by standardized unexpected earnings (SUE), which is the difference between actual and expected earnings divided by the stock price at the end of the period (Truong and Corrado, 2014).

$$
S U E_{i, q}=\frac{E_{i, q}-F_{i, q}}{P_{i, q}}
$$

With $E_{i, q}$ is the earnings per share ratio of stock $i$ in quarter $q$. terminal

$F_{i, q}$ is is the forecasted earnings per share of stock $i$ in quarter $q$ obtained from the Bloomberg

$P_{i, q}$ is the price of stock $i$ at the end of quarter $q$.

\section{Control variables}

The company size (SIZE) is represented by the market capitalization of the company and the book-tomarket ratio $(B M)$ is estimated by dividing the book value by the market value of the firm, which control for the growth opportunities of the firm. SIZE is supposed to be negatively associated with the immediate stock price reacting to the earnings announcements because the earnings announcement contains the information which is negatively associated with the firm's information environment (Lobo and Mahmoud, 1989; Truong and Corrado, 2014). BM is also found to be negatively related to the abnormal return around earnings announcements (Truong and Corrado, 2014). 


\section{Regression models}

1. To examine the impact of Options trading volume on the response of stock prices to earnings announcements. the following models are estimated:

$$
\begin{aligned}
& C^{A} R_{i, q}=\beta_{0}+\beta_{1} \text { OPTVOL }_{i, q}+\beta_{2} \operatorname{SIZE}_{i, q}+\beta_{3} B M_{i, q}+\varepsilon_{i, q} \\
& \text { CAR }_{i, q}=\beta_{0}+\beta_{1} \text { CALVOL }_{i, q}+\beta_{2} S I Z E_{i, q}+\beta_{3} B M_{i, q}+\varepsilon_{i, q} \\
& \text { CAR }_{i, q}=\beta_{0}+\beta_{1} \text { PUTVOL }_{i, q}+\beta_{2} \operatorname{SIZE}_{i, q}+\beta_{3} B M_{i, q}+\varepsilon_{i, q}
\end{aligned}
$$

The regression models are implemented to examine the impacts of total option trading volume of stock $i$ in quarter $q\left(\mathrm{OPTVOL}_{\mathrm{i}, q}\right)$, call option trading volume of stock $i$ on quarter $q\left(\mathrm{CALVOL}_{\mathrm{i}, q}\right)$ and put option

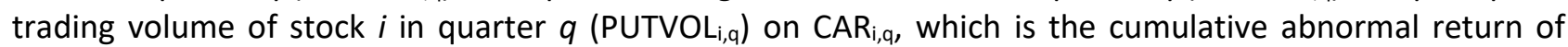
stock $\mathrm{i}$ around the earnings announcement in quarter $\mathrm{q}$ (day $-1,0$ and 1). OPTVOL $\mathrm{i}, \mathrm{q}, \mathrm{CALVOL}_{\mathrm{i}, q}$, and PUTVOL $_{i, q}$ is the daily average total, call, and put options trading volume of stock $i$ in quarter $q$, which is measured by the option trading volume of stock $i$ in quarter $q$ deivided by the number of trading days in quarter q. $S I Z E_{i, q}$ represents the initial market value of the firm i and $B M_{i, q}$ is the initial book-to-market ratio of company $i$ in quarter $q$.

2. To additionally examine the interaction between earnings surprise proxied by the standardized unexpected earnings (SUE) and the other independent and control variables, the following models are then estimated:

$$
\begin{aligned}
& C A R_{i, q}=\beta_{0}+\beta_{1} S U E_{i, q}+\beta_{2} S U E_{i, q} * O P T V O L_{i, q}+\beta_{3} S U E_{i, q} * S I Z E_{i, q}+\beta_{3} S U E_{i, q} * B M_{i, q}+\varepsilon_{i, q}(8) \\
& C A R_{i, q}=\beta_{0}+\beta_{1} S U E_{i, q}+\beta_{2} S U E_{i, q} * C A L V O L_{i, q}+\beta_{3} S U E_{i, q} * S I Z E_{i, q}+\beta_{3} S U E_{i, q} * B M_{i, q}+\varepsilon_{i, q} \text { (9) } \\
& \mathrm{CAR}_{i, q}=\beta_{0}+\beta_{1} \mathrm{SUE}_{i, q}+\beta_{2} S U E_{i, q} * \mathrm{PUTVOL}_{i, q}+\beta_{3} \operatorname{SUE}_{i, q} * \operatorname{SIZE}_{i, q}+\beta_{3} \operatorname{SUE}_{i, q} * B M_{i, q}+\varepsilon_{i, q} \text { (10) }
\end{aligned}
$$

Estimation of these models aids the assessment of the earnings response coefficients of firms with different levels of total, call and put options trading volume respectively in relation to the cumulative abnormal returns. $\mathrm{SUE}_{\mathrm{i}, \mathrm{q}}$ is the earning surprise proxied by the standardized unexpected earnings of stock $i$ in quarter q. CAR $\mathrm{R}_{\mathrm{i}, \mathrm{q}}$ is the cumulative abnormal return of stock $i$ related to the event in quarter $q . \mathrm{SIZE}_{\mathrm{i}, \mathrm{q}}$ is the initial market capitalization of the firm $i$ in quarter $q$ and $\mathrm{BM}_{\mathrm{i}, \mathrm{q}}$ is the corresponds to the initial book-tomarket ratio of stock $i$ in quarter $q$. OPTVOL $L_{i, q}, C$ CLVOL $_{i, q}$, PUTVOL $_{i, q}$ represent the total, call, and put options trading volume of stock $i$ in quarter $q$.

\section{Analysis and findings}

\section{Data Description}

Data related to quarterly announcement dates (event date 0) for each company from the first quarter of 2010 to the last quarter of 2017 is recorded (there are 4 announcement dates in a year corresponds to 4 quarters), and the immediate stock return for each company related to these announcement dates (the returns are calculated for date $-1,0$ and 1 ) is obtained later, from a Bloomberg terminal. Then, the market capitalization (SIZE) and book-to-market (BM) value for each company regarding each fiscal year from 2010 to 2017 are obtained and collected, before collecting the actual and forecasted earnings-per-share ratio for each company regarding to each quarter in order to estimate the standardized unexpected earning (SUE), both also from the Bloomberg terminal. Finally, the data for options trading volume (OPTVOL, CALVOL and PUTVOL) is collected from the official website of CBOE (CBOE, no date).

In total, the sample includes the relevant data of 90 companies listed on S\&P 100 from quarter 1 of 2009 to quarter 4 of 2017 . There are totally 102 institutions listed on the S\&P 100 index, however, data is available for just 90 companies from 2010 to 2017; the other 12 companies for whom data is not available are excluded. In total, there are 2880 observations. As the companies are in the S\&P100, they represent the largest and well-known companies in the US and globally. The data set is a balanced panel.

Table 1 below represents the statistical summary of the variables utilized in this study. 
Table 1. Descriptive statistics of the variables

\begin{tabular}{|l|c|c|c|c|c|c|c|}
\hline \multicolumn{1}{|c|}{ Statistic } & CAR & OPTVOL & CALVOL & PUTVOL & SUE & SIZE & BM \\
\hline Mean & 0.002433 & 8556.571 & 5293.217 & 3263.353 & -0.00049 & $9.55 \mathrm{E}+10$ & 0.495426 \\
\hline Median & 0.000782 & 3115.491 & 1789.888 & 1229.823 & 0.000487 & $6.67 \mathrm{E}+10$ & 0.332375 \\
\hline Maximum & 0.460508 & 259064.7 & 205517.2 & 102383.9 & 0.460474 & $6.40 \mathrm{E}+11$ & 24.45655 \\
\hline Minimum & -0.2909 & 35.80645 & 25.80645 & 8.126984 & -1.45191 & $2.94 \mathrm{E}+09$ & -0.23104 \\
\hline Std. Dev. & 0.044879 & 20450.33 & 13436.41 & 7284.112 & 0.034156 & $8.29 \mathrm{E}+10$ & 1.103212 \\
\hline Observations & 2880 & 2880 & 2880 & 2880 & 2880 & 2880 & 2880 \\
\hline
\end{tabular}

The sample data is examined with histograms.

Source: Authors' work

\section{Cumulative Abnormal Returns (CAR)}

The distribution of Cumulative Abnormal Returns in the sample is as below in Figure $5 \mathrm{a}$; the mean was positive at $0.002433(0.24 \%)$ and the standard deviation was $0.0449(4.49 \%)$. The median was positive and at $0.00078(0.078 \%)$. Overall, approximately $50 \%$ of the sample had negative CARs and $50 \%$ of the sample had positive CARs.

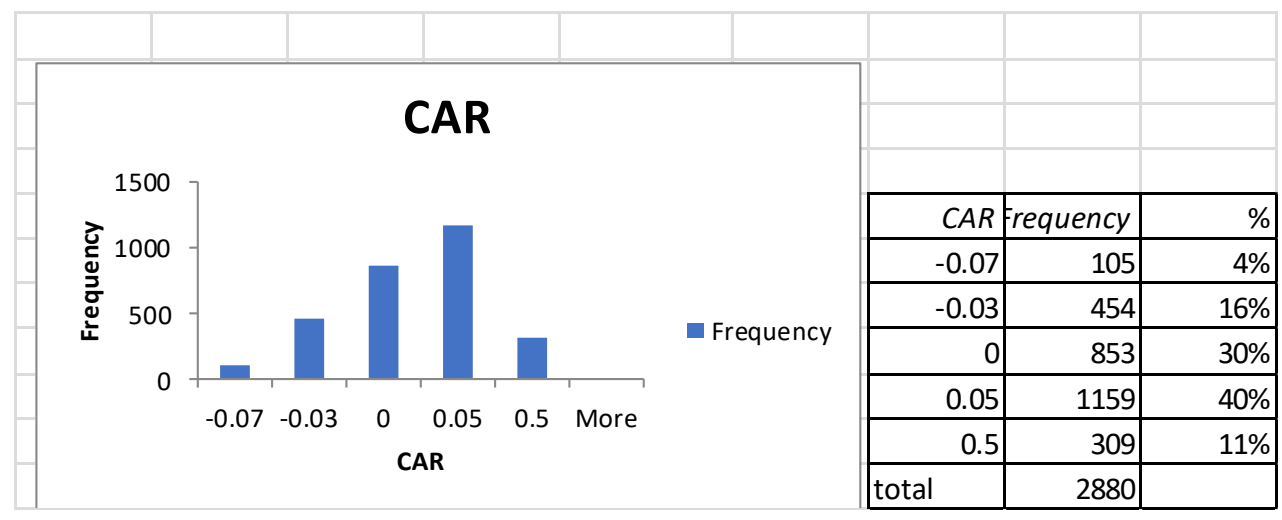

Source: Authors' work

Figure 4a. Distribution of CAR in the sample

Total Option trading volumes in a quarter (OPTVOL)

The distribution of the total option trading volumes in a quarter in the sample is as in Figure $5 b$ below; the mean total option trading volume was 8,557 and the standard deviation was 20,450 . The median was 3,115 . $70 \%$ of the sample were trading between $500-8000$ shares.

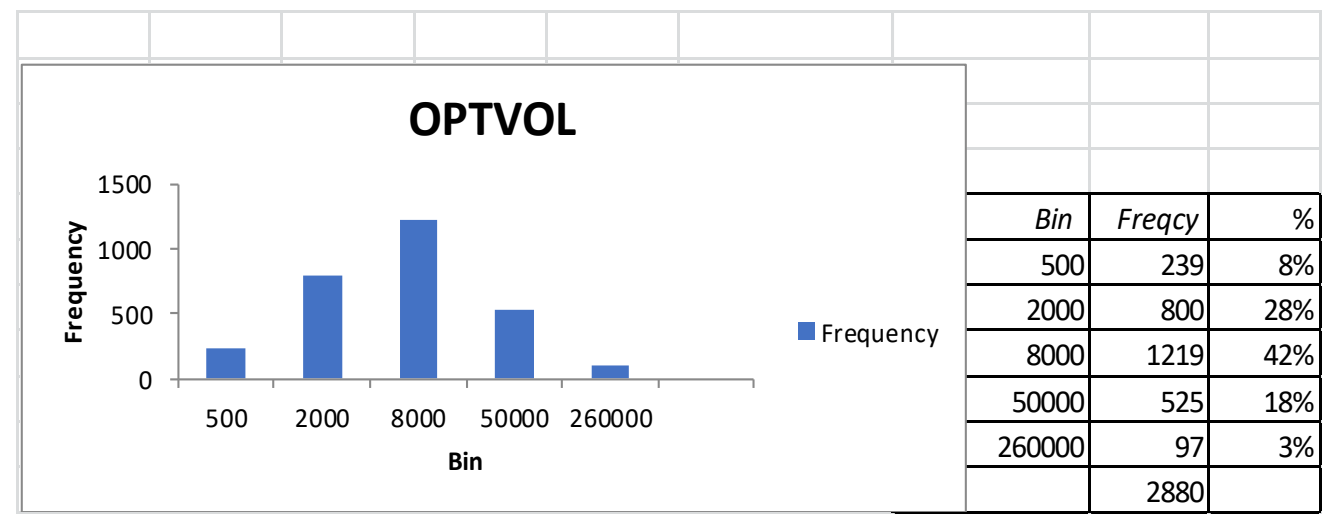

Source: Authors' work

Figure $4 b$. Distribution of OPTVOL in the sample. 
Total Call Option trading volumes in a quarter (CALVOL)

The distribution of the call option trading volumes in a quarter in the sample is as in Figure $5 \mathrm{c}$ below; the mean call option trading volume was 5,293 and the standard deviation was 13,436 . The median was $1,790.55 \%$ of the sample was trading between $800-5,500$ shares.

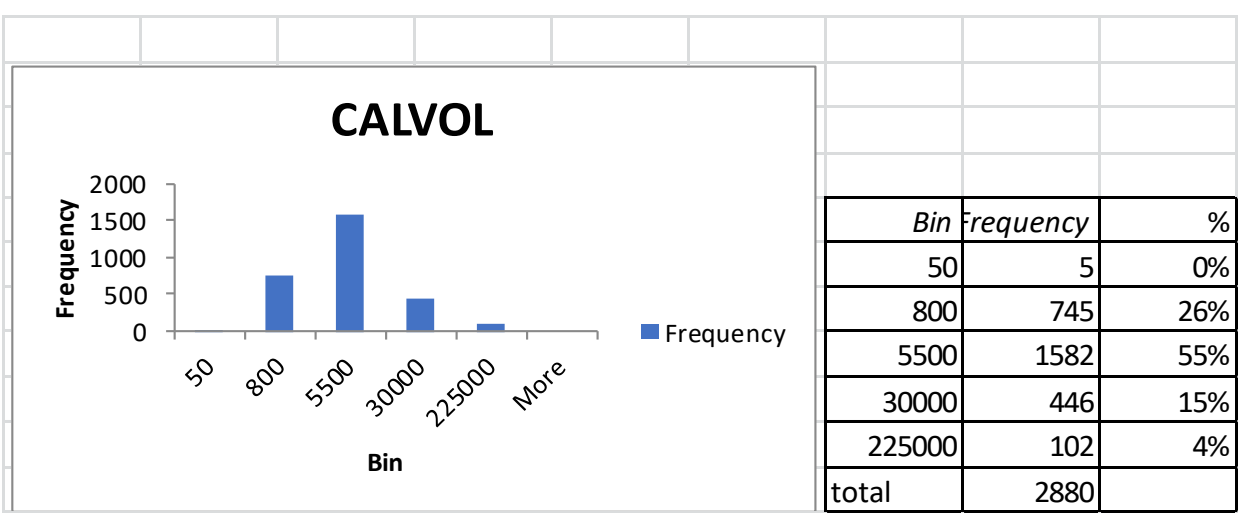

Source: Authors' work

Figure 4c. Distribution of CALVOL in the sample

Total Put Option trading volumes in a quarter (PUTVOL)

The distribution of the put option trading volumes in a quarter in the sample is as in Figure $5 \mathrm{~d}$ below; the mean put option trading volume was 3,263 and the standard deviation was 7,284 . The median was $1,229.67 \%$ of the sample was trading between $200-3,000$ shares.

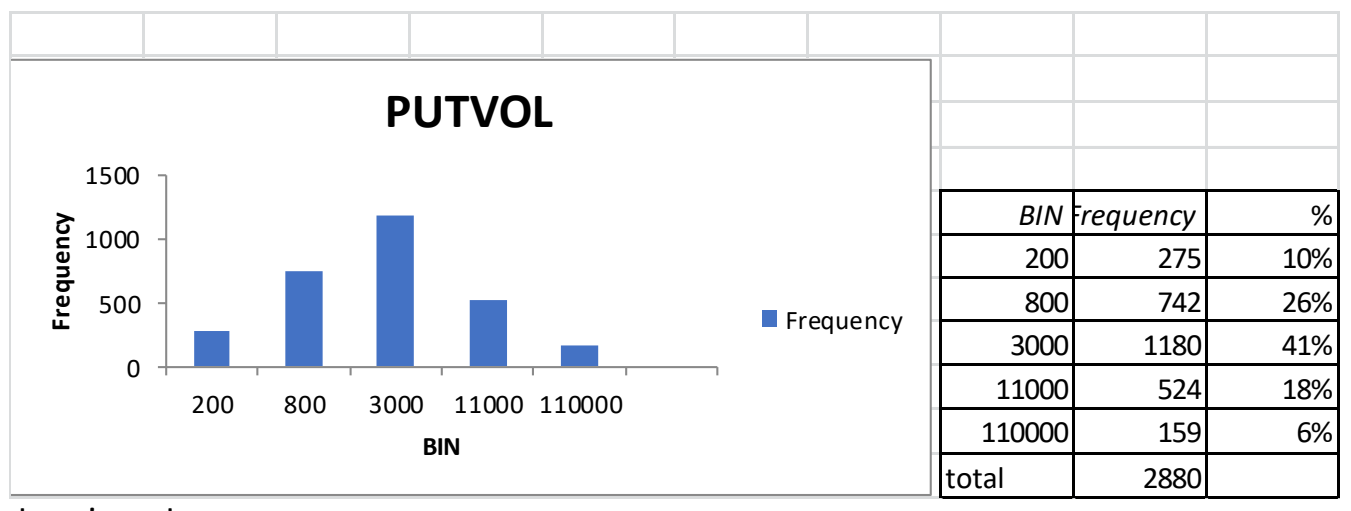

Source: Authors' work

Figure 4d. Distribution of PUTVOL in the sample

Earnings Surprise Variable (SUE)

The distribution of the Earnings Surprise Variable (SUE) is as in Figure 5e below; the mean was $0.00049(-0.049 \%)$ and standard deviation was 0.03415 (3.42\%). The median was 0.000487 . About $35 \%$ of the sample had negative values for SUE.

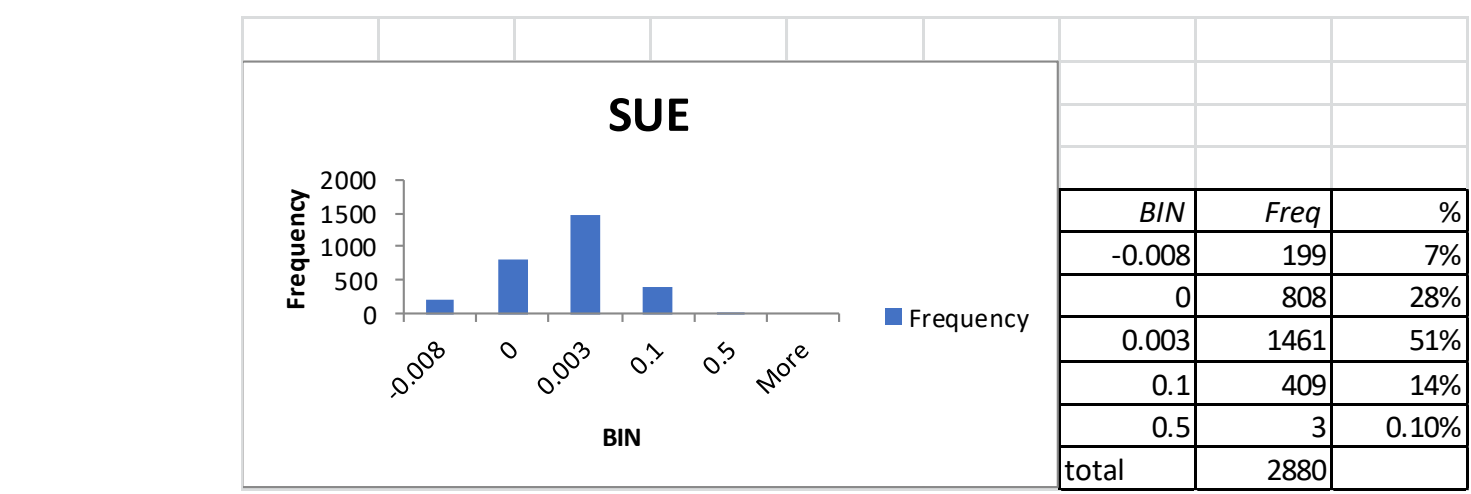

Source: Authors' work

Figure 4e. Distribution of SUE in the sample 
Size (Market Capitalisation)

The distribution of the Market Capitalisation of the companies in the sample is as in Figure $5 f$ below; the mean was $\$ 95.5 \mathrm{bn}$ and standard deviation was $\$ 82.9 \mathrm{bn}$. The median was $\$ 66.7 \mathrm{bn}$. $45 \%$ of the sample companies had a market capitalisation between $\$ 40 \mathrm{bn}-\$ 100 \mathrm{bn}$, while $33 \%$ of the sample had a market capitalisation above $\$ 100 \mathrm{bn}$.

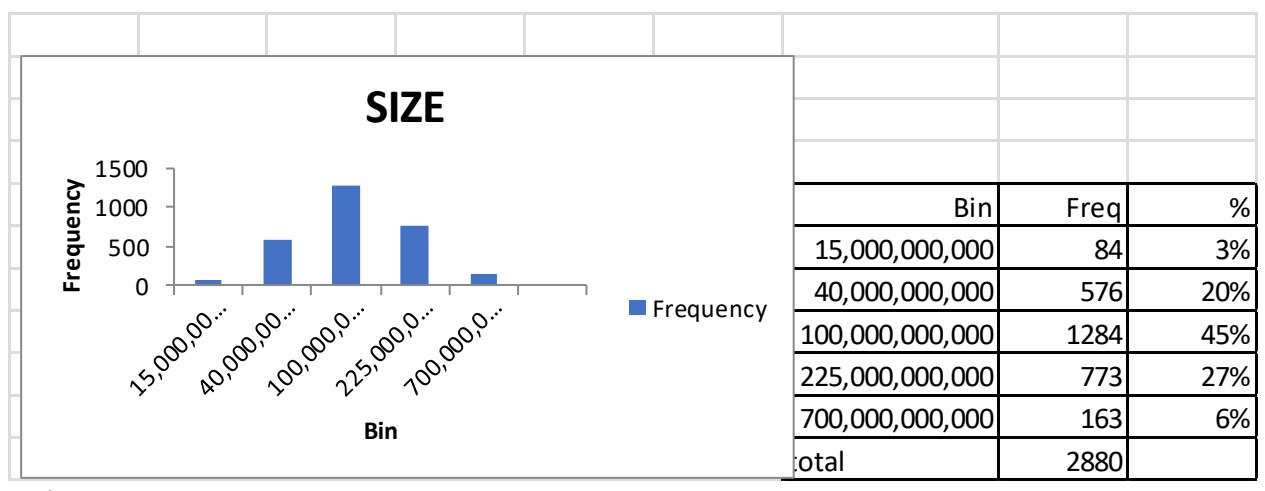

Source: Authors' work

Figure $4 f$. Distribution of Size in the sample

Book to Market ratio (BM)

The distribution of the Book to Market ratio in the sample is as in Figure $5 \mathrm{~g}$ below; the mean was 0.495 and standard deviation was 1.103 . The median was 0.3323 . Less than $1 \%$ of the sample had negative Book to Market (BM) ratios; the majority ranged between 0.1 and 0.5 (58\%).

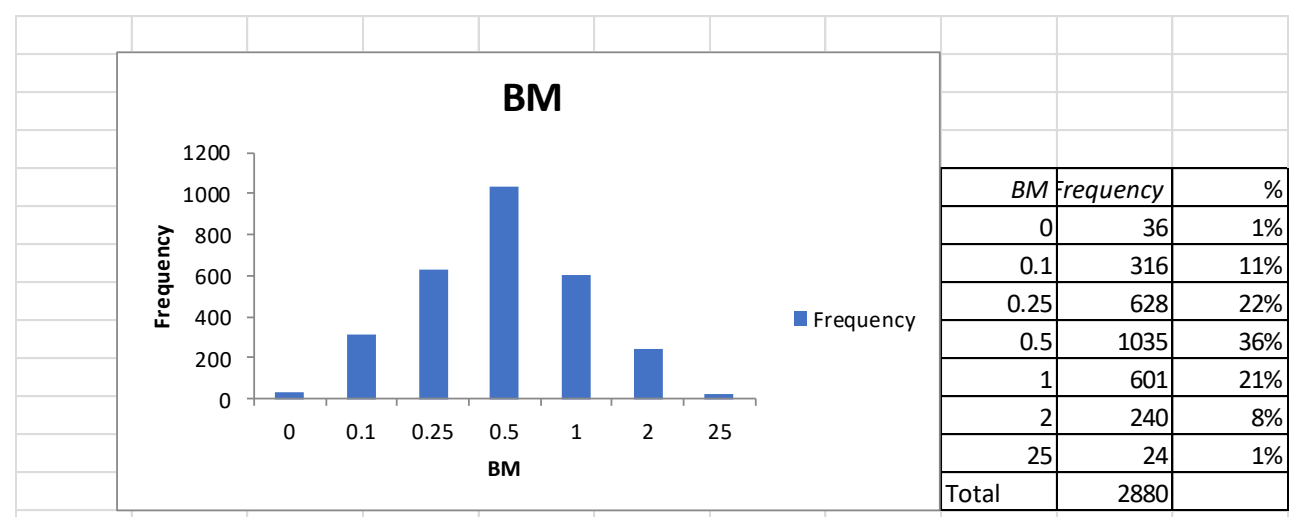

Source: Authors' work

Figure $4 g$. Distribution of BM ratio in the sample

\section{Correlation matrix}

Table 2. Correlation matrix of the variables

\begin{tabular}{|l|l|l|l|l|l|l|l|}
\hline Variable & CAR & OPTVOL & CALVOL & PUTVOL & SUE & SIZE & BM \\
\hline CAR & 1.000000 & & & & & & \\
\hline OPTVOL & 0.023848 & 1.000000 & & & & & \\
\hline CALVOL & 0.023009 & 0.992970 & 1.000000 & & & & \\
\hline PUTVOL & 0.024509 & 0.975873 & 0.943169 & 1.000000 & & & \\
\hline SUE & 0.020872 & 0.011072 & 0.011729 & 0.009451 & 1.000000 & & \\
\hline SIZE & -0.052642 & 0.486901 & 0.455475 & 0.526808 & 0.027248 & 1.000000 & \\
\hline BM & 0.004882 & 0.057449 & 0.062758 & 0.045526 & -0.452866 & -0.092383 & 1.000000 \\
\hline
\end{tabular}

Source: Authors' work 
Table 2 illustrates the correlation matrix between the variables utilized in this study. The dependent variable $(C A R)$ is moderately correlated to the three independent variables of this study (OPTVOL, CALVOL and PUTVOL), which are $0.023,0.023$ and 0.024 respectively, indicating that there is a positive correlation between the dependent and explanatory variables. The 2 control variables (SIZE and BM) are found to be slightly correlated with the dependent variable, whose correlation coefficients are approximately -0.052 and 0.005 respectively. These variables play the crucial roles in assessing the interaction between the immediate stock prices response to earning announcements and option trading volumes. While the $B M$ is positively correlated with CAR, there is a negative relation between SIZE and CAR.

In total, the correlation level between the independent variables is low, suggesting that the information provided by these explanatory variables is distinct from each other. In other words, there is no such a linear relationship between each pair of the independent variables, and the multicollinearity problem is thus eliminated, implying that the regression model is BLUE. The highest correlation degrees are found between SIZE and the three main independent variables (OPTVOL, CALVOL and PUTVOL), which are about $0.487,0.455$ and 0.527 respectively. However, these levels are not high enough to cause the multicollinearity problem, and the SIZE is not supposed to be the perfect substitution for any one of the three main independent variables.

Data is structured as a panel with 90 cross-sections, and estimations are possible by the pooled OLS, Fixed Effects and Random Effects regression models. The pooled OLS method treats the cross-sections indifferently, and estimates a common constant intercept for all cross-sectional observations. By contrast, the Fixed Effects method takes into consideration the different constants for each section by including the unique dummy variables for each section. The Random Effects method is quite similar to the Fixed Effects method except that the latter controls for the constants are random instead of being fixed.

\section{Test for stationarity of data}

It is necessary for the variables in a regression model to be stationary. This study uses panel data with 90 different cross-sections from 2010 to 2017. Therefore, there is a chance that the variables are not stationary. A panel unit root test is conducted on CAR, OPTVPOL, CALVOL, PUTVOL, SUE, SIZE and BM and the results are given in the table below:

Table 3. Result of panel unit root tests on: CALVOL, SUE, SIZE, PUTVOL, OPTVOL, BM, CAR

Group unit root test: Summary

Series: CALVOL, SUE, SIZE, PUTVOL, OPTVOL, BM, CAR

Date: 03/26/19 Time: 21:54

Sample: $1 / 01 / 201011 / 19 / 2017$

Exogenous variables: Individual effects

Automatic selection of maximum lags

Automatic lag length selection based on SIC: 0 to 16

Newey-West automatic bandwidth selection and Bartlett kernel

\begin{tabular}{|c|c|c|c|c|}
\hline Method & Statistic & Prob.** & $\begin{array}{l}\text { Cross- } \\
\text { sections }\end{array}$ & Obs \\
\hline \multicolumn{5}{|c|}{ Null: Unit root (assumes common unit root process) } \\
\hline Levin, Lin \& Chu t* & -22.6210 & 0.0000 & 7 & 20102 \\
\hline \multicolumn{5}{|c|}{ Null: Unit root (assumes individual unit root process) } \\
\hline Im, Pesaran and Shin W-stat & -45.0822 & 0.0000 & 7 & 20102 \\
\hline ADF - Fisher Chi-square & 550.354 & 0.0000 & 7 & 20102 \\
\hline PP - Fisher Chi-square & 675.673 & 0.0000 & 7 & 20153 \\
\hline
\end{tabular}

** Probabilities for Fisher tests are computed using an asymptotic Chi-square distribution. All other tests assume asymptotic normality.

The Panel unit root test confirms the rejection of the null hypothesis that there is a unit root in the data tested. 
Hence hereon the following equations are estimated in section $\mathrm{V}$

$$
\begin{aligned}
& C A R_{i, q}=\beta_{0}+\beta_{1} O P T V O L_{i, q}+\beta_{2} S I Z E_{i, q}+\beta_{3} B M_{i, q}+\varepsilon_{i, q} \\
& C A R_{i, q}=\beta_{0}+\beta_{1} C A L V O L_{i, q}+\beta_{2} S I Z E_{i, q}+\beta_{3} B M_{i, q}+\varepsilon_{i, q} \\
& \mathrm{CAR}_{i, q}=\beta_{0}+\beta_{1} \text { PUTVOL }_{i, q}+\beta_{2} \text { SIZE }_{i, q}+\beta_{3} B M_{i, q}+\varepsilon_{i, q}
\end{aligned}
$$

And in section $\mathrm{VI}$

$$
\begin{aligned}
& C A R_{i, q}=\beta_{0}+\beta_{1} S U E_{i, q}+\beta_{2} S U E_{i, q} * O P T V O L_{i, q}+\beta_{3} S U E_{i, q} * S I Z E_{i, q}+\beta_{3} S U E_{i, q} * B M_{i, q}+\varepsilon_{i, q} \\
& C A R_{i, q}=\beta_{0}+\beta_{1} S U E_{i, q}+\beta_{2} S U E_{i, q} * C A L V O L_{i, q}+\beta_{3} S U E_{i, q} * S I Z E_{i, q}+\beta_{3} S U E_{i, q} * B M_{i, q}+\varepsilon_{i, q} \\
& C A R_{i, q}=\beta_{0}+\beta_{1} S U E_{i, q}+\beta_{2} S U E_{i, q} * P_{i, q} \operatorname{PULL}_{i, q}+\beta_{3} S U E_{i, q} * S I Z E_{i, q}+\beta_{3} S U E_{i, q} * B M_{i, q}+\varepsilon_{i, q}
\end{aligned}
$$

The notations of which have been earlier explained. Pooled, Fixed and Random models are estimated and appropriate models selected using the redundant fixed effects or the Hausmann test as appropriate.

\section{Options trading volume and the immediate stock prices response to the earnings announcements}

For models (1), (2) and (3) the Random Effects model is first estimated and the Hausman test is applied to determine whether the Random effects or Fixed Effects model is better.

Table 3. The results of the Hausman test for regression models (1), (2) and (3)

\begin{tabular}{|l|c|c|c|}
\hline Hausman test & Model 1 & Model 2 & Model 3 \\
\hline Chi-Square statistic & 15.40832 & 13.38186 & 19.0622 \\
\hline P-value & 0.0015 & 0.0039 & 0.0003 \\
\hline
\end{tabular}

Source: Authors' work

Table 4 represents the results of the Hausman test. The $p$-values of the three tests regarding the

\begin{tabular}{|c|c|c|c|c|c|c|}
\hline \multicolumn{7}{|c|}{ Dependent Variable: CAR } \\
\hline \multicolumn{7}{|c|}{ Method: Panel Least Squares } \\
\hline \multicolumn{7}{|c|}{ Sample: 2010Q1 2017Q4 } \\
\hline \multicolumn{7}{|l|}{ Periods included: 32} \\
\hline \multicolumn{7}{|c|}{ Cross-sections included: 90} \\
\hline \multicolumn{7}{|c|}{ Total panel (balanced) observations: 2880} \\
\hline & Model 1 & & Model 2 & & Model 3 & \\
\hline Variable & Coeff & Prob. & Coeff & Prob. & Coeff & Prob. \\
\hline C & 0.008352 & $0.0014 * * *$ & 0.008082 & $0.0019 * * *$ & 0.008749 & $0.0009 * * *$ \\
\hline OPTVOL & $-1.32 \mathrm{E}-07$ & $0.0988 *$ & & & & \\
\hline CALVOL & & & $-1.56 \mathrm{E}-07$ & 0.1683 & & \\
\hline PUTVOL & & & & & $-5.05 E-07$ & $0.0393 * *$ \\
\hline SIZE & $-5.16 \mathrm{E}-14$ & $0.0305 * * *$ & $-5.19 \mathrm{E}-14$ & $0.0296 * *$ & $-5.05 E-14$ & $0.0341^{* *}$ \\
\hline BM & 0.000285 & 0.7662 & 0.000269 & 0.7786 & 0.000317 & 0.7413 \\
\hline \multicolumn{7}{|l|}{ Cross-section fixed } \\
\hline R-squared & & 0.062578 & & 0.0623 & & 0.06309 \\
\hline \multicolumn{2}{|l|}{ Adjusted R-squared } & 0.031634 & & 0.031347 & & 0.032163 \\
\hline S.E. of regression & & 0.044163 & & 0.04417 & & 0.044151 \\
\hline \multicolumn{2}{|l|}{ Sum squared resid } & 5.435701 & & 5.437312 & & 5.432731 \\
\hline Log likelihood & & 4945.939 & & 4945.513 & & 4946.726 \\
\hline \multicolumn{2}{|l|}{ Durbin-Watson stat } & 2.086047 & & 2.012686 & & 2.088182 \\
\hline F-statistic & & $2.0222 * * *$ & & $2.0854 * * *$ & & $2.0399 * * *$ \\
\hline Prob(F-statistic) & & 0.0000 & & 0.0000 & & 0.0000 \\
\hline
\end{tabular}
three regression models of this study are all smaller than 0.05 , indicating that the null hypothesis of the Random Effects model being better can be rejected. Therefore, the Fixed Effects model is the best fit for the data sample of this study. The results for the Fixed Effects model estimation for the models (1), (2) and (3) are as below in Table 4.

Table 4. The results of regressions models (1), (2) and (3) applying the Fixed Effects method

$* / * * / * * *$ : significance levels of $10 \%, 5 \%$ and $1 \%$ respectively

Source: Authors' work 
Model (1) is found to be valid with a highly significant $\mathrm{F}$ statistic at the $1 \%$ level, and an R-squared of $6 \%$, and other satisfactory statistics. The first column of table 6 represents the statistical results of the fixed effect regressions model (1). The total options trading volume $O P T V O L$ is found to be relevant to explain for CAR with the significance level of $10 \%$. The coefficient of OPTVOL $(-1.32 \mathrm{E}-07)$ indicates that when the OPTVOL increases by 1 unit, the CAR will decrease by $1.32 \mathrm{E}-07$ units. The coefficient of the control variable SIZE is highly significant at the $1 \%$ level; and indicates that when the SIZE variable increases by 1 unit, the CAR will decrease by $5.16 \mathrm{E}-14$ units. The coefficient of the other control variable $B M$ is found to be insignificant in its effect on CAR. In summary, total options trading volume and size have weakly significant effects on the CAR to earnings news as represented by the cumulative abnormal return in the three days around the announcement. CAR is larger for the firms with lower total options trading volume and size but not the book to market ratio which is a value measure.

The second and third columns illustrate the results of the regression models (2) and (3) of this study. Both models are statistically valid with F-statistics at the $1 \%$ level, and other satisfactory statistics. While the call option trading volumes, CALVOL is irrelevant to the stock prices variations around the earnings announcements, the put options trading volume PUTVOL is found to be relevant to explain CAR with a high significance level of $5 \%$. The coefficient of PUTVOL is $-5.05 \mathrm{E}-07$, indicating the negative association between the put options trading volume and the immediate stock prices response to earnings announcements represented by the CAR. SIZE is found to be strongly significant in both regression models (2) and (3) with the significance level of $1 \%$ and $5 \%$ respectively. The coefficient of SIZE in the regression (2) is $-5.19 E-14$, which is slightly larger as compared to the regression model (3) in which it is $-5.05 \mathrm{E}-14$.

In summary, of the various option metrics, the put options trading volume is the most significant relevant metric to explain stock price response to earnings announcements proxied by the cumulative abnormal return. In all three models, size is significant with a negative effect, but not the book to market (BM) variable.

\section{Options trading volume and earnings response coefficients}

Adopting from Mendenhall and Fehrs (1999) and Truong and Corrado (2014), the standardized unexpected earnings (SUE) is utilized as an interaction variable to investigate if the firms with different level of options trading volume manifest different earnings response coefficients relating to the announcement period, after controlling for the firm size (SIZE) and the firm's book-to-market ratio (BM). The interaction variables are generated from the interaction between (SUE) and the primary independent variables (OPTVOL, CALVOL and PUTVOL) to interpret the difference between the level of the earnings response coefficient between firms with different magnitude of total options trading volume, call and put options trading volume respectively in relation to the cumulative abnormal returns (CAR). The earning surprise, which is proxied by the standardized unexpected earnings (SUE) is also treated an independent variable in the three different regression models (4), (5) and (6)), and the other independent and control variables are linked to SUE.

Here the Pooled and Fixed Effects can be estimated and therefore the redundant Fixed Effects test is conducted to ascertain whether the Fixed Effects or Pooled model is better. The results of the redundant Fixed Effects test are shown in Table 5 below:

Table 5. The results of the redundant Fixed Effects test for regression models (4), (5) and (6)

Source: Authors' work

\begin{tabular}{|l|c|c|c|}
\hline Redundant Fixed Effects test & Model 4 & Model 5 & Model 6 \\
\hline Chi-Square statistic & 178.804 & 178.78 & 178.789 \\
\hline P-value & 0.0000 & 0.0000 & 0.0000 \\
\hline
\end{tabular}

The $p$-values of the three tests regarding the three regression models of this study are all less than than 0.05 , indicating that the null hypothesis of the Pooled effects model being better than the Fixed Effects model is rejected. Therefore, the Fixed Effects model is best for (4), (5) and (6).

The results for the Fixed Effects model estimation for models (4), (5) and (6) are as below in Table 6.

Fixed Effects method estimation for models (4),(5) and (6), Dependent variable: CAR(-1,1). 
Table 6. The results of regressions models (4), (5) and (6) applying the Fixed Effects method

\begin{tabular}{|c|c|c|c|c|c|c|}
\hline \multicolumn{7}{|c|}{ Dependent Variable: CAR } \\
\hline \multicolumn{7}{|c|}{ Method: Panel Least Squares } \\
\hline \multicolumn{7}{|c|}{ Sample: 2010Q1 2017Q4 } \\
\hline \multicolumn{7}{|c|}{ Periods included: 32} \\
\hline \multicolumn{7}{|c|}{ Cross-sections included: 90} \\
\hline \multicolumn{7}{|c|}{ Total panel (balanced) observations: 2880} \\
\hline & Model 4 & & Model 5 & & Model 6 & \\
\hline Variable & Coeff. & Prob. & Coeff. & Prob. & Coeff. & Prob. \\
\hline C & 0.002373 & $0.004 * * *$ & 0.002378 & $0.004 * * *$ & 0.002372 & $0.004 * * *$ \\
\hline SUE & 0.070012 & 0.5395 & 0.06497 & 0.5705 & 0.087069 & 0.4438 \\
\hline OPTVOL*SUE & $6.27 \mathrm{E}-06$ & $0.0645^{*}$ & & & & \\
\hline CALVOL*SUE & & & $8.14 \mathrm{E}-06$ & $0.0944 *$ & & \\
\hline PUTVOL*SUE & & & & & $2.13 \mathrm{E}-05$ & $0.0382^{* * *}$ \\
\hline SIZE*SUE & $-4.97 \mathrm{E}-13$ & 0.6865 & $-3.19 \mathrm{E}-13$ & 0.7929 & $-8.25 \mathrm{E}-13$ & 0.5162 \\
\hline BM*SUE & -0.00504 & 0.3006 & -0.00428 & 0.3719 & -0.00654 & 0.1942 \\
\hline \multicolumn{7}{|l|}{ Cross-section fixed } \\
\hline R-squared & & 0.062055 & & 0.061846 & & 0.062352 \\
\hline \multicolumn{2}{|c|}{ Adjusted R-squared } & 0.030745 & & 0.03053 & & 0.031052 \\
\hline S.E. of regression & & 0.044183 & & 0.044188 & & 0.044176 \\
\hline \multicolumn{2}{|l|}{ Sum squared resid } & 5.438734 & & 5.439944 & & 5.437014 \\
\hline \begin{tabular}{|l|} 
Log likelihood \\
\end{tabular} & & 4945.136 & & 4944.815 & & 4945.591 \\
\hline \multicolumn{2}{|c|}{ Durbin-Watson stat } & 2.080087 & & 2.079638 & & 2.081136 \\
\hline F-statistic & & $1.981977^{* * *}$ & & $1.97487^{* * *}$ & & $1.99208 * * *$ \\
\hline Prob(F-statistic) & & 0.0000 & & 0.0000 & & 0.0000 \\
\hline
\end{tabular}

$* / * * * * *$ : significance levels of $10 \%, 5 \%$ and $1 \%$ respectively

Source: Authors' work

Model (4) is found to be valid with a highly significant $F$ statistic at the $1 \%$ level, with an R-squared of 0.0621 and other satisfactory statistics. The first column of table 6 represents the statistical results of the Fixed Effects regressions model (4). SUE is found to be not statistically relevant to the CAR. The coefficient of OPTVOL*SUE is found to be weakly significant in its effect on CAR with a significance level of $10 \%$. The coefficient of OPTVOL*SUE implies that CAR is higher by 6.27E-06 for an increase in 1 unit of OPTVOL*SUE. The interaction coefficients of the other two control variables, which are SIZE*SUE and SIZE*BM, are not significant.

The second and third columns illustrate the results of the regression models (5) and (6) of this study. Both models are statistically valid with F-statistics at the $1 \%$ level and other satisfactory statistics. Again the coefficients of SUE are found to be insignificant while the coefficients of CALVOL*SUE and PUTVAL ${ }^{*} S U E$ are found to be significant to explain for CAR with the significance level of $10 \%$ and $5 \%$ levels respectively, with the coefficient of PUTVOL*SUE (2.13E-05) being higher and more significant. The coefficient of PUTVOL *SUE (2.13E-05) implies that CAR is higher by $2.13 \mathrm{E}-5$ for an increase in 1 unit of PUTVOL*SUE. The coefficients of the other two interaction control variables, which are SIZE*SUE and SIZE*BM, are again not significant.

In summary, after accounting for the interaction of the earnings surprise variable (SUE) with the trading volumes of total options, call option volumes, put option volumes, size and the book to market ratio, the put options trading volume metric interacting with the earnings surprise coefficient is the most significant in explaining stock price response to earnings announcements proxied by the cumulative abnormal return, but not size or book to market ratios.

In conclusion of the findings, this research has shown that put option trading volumes and size, on their own, have the most significant effects on the CAR of earnings announcements in the post crisis era. And when the interaction of the earnings surprise coefficient is taken on options trading volumes (total, call and put), size and the $B M$ ratio, put option trading volumes again have the most effect (highest significance and size of coefficients) while the earnings surprise coefficient on its own or the interaction of the earnings surprise coefficient on size and book to market are insignificant. 


\section{Discussions}

This study demonstrated that option trading volumes are negatively related to the immediate stock price response to earnings announcements, with the coefficient of the put options trading volume being more significant. Moreover, the size coefficient is significant and negative in all three models (1), (2) and (3), showing that the impact of earnings announcements is lower on smaller companies whose options are traded on the stock exchange. Therefore, smaller company stocks with more active option trading activity are less exposed to the abnormal returns in stock price response, related to earnings announcements. The volume of options trading generally has a stabilising effect on stock price response to earnings announcements with a more significant effect on smaller companies, for whom information is more opaque than for larger companies. The role of option trading volumes on lending stability to stock prices and preferred by informed traders stated in research (Black, 1975; Damodaran et al. (1991), Easley, O'Hara and Srinivas, 1998), is thus clear. The mean of the CAR variable is positive (0.002433), but the median is lower (0.000782), implying that stock price response are usually lower than the mean. The intercepts of the regressions in models (1), (2) and (3) are all highly significant and positive and greater than the mean of the $C A R$ variable. In relation to the findings the put option trading volumes have the highest significance in their effect on CAR (Model 3): Put options give a trader the right to sell at some price, and are behaviourally preferred in an environment of uncertainty, which means that although the market had a lower volatility (VIX) in the post crisis period, the majority of traders were hedging against a downturn.

However, when the effect of the earnings surprise variable is taken into account, in models (4), (5) and (6), the intercepts are significant but lower than the mean value of CAR. This reverses the signs of the significant coefficients, towards reaching the mean, but again the interaction of the earnings surprise variable on the put volume variable has the highest value and most significance, implying also that the magnitude of the earnings surprise variable is important in determining the extent of response of stock prices $(C A R)$, while put options maintain their relevance. This is in line with previous research that stock prices react more positively to good news than bad news (Mazouz et al. (2015). The coefficient of SUE or the interaction of SUE with size is not significant; so this means CAR is independent of this interaction, and size is not relevant. This can be explained by the fact that the sample is from SP100 companies, which are already in the larger category of companies and resolution of information uncertainties as in Kothari et al (1991), are not an issue. Equally the insignificance of the coefficient of the interaction of SUE with the BM ratio, implies that the CARs on Value stocks are not any different on stock price response to earnings' surprises, than Growth stocks. This too, by implication means that there is to a large extent, a rational component to the valuation of a share as a present value of future cash flows.

In summary, even in the post crisis period, the volume of option trading activities is found to influence the response of stock prices to earning announcements. This finding supports the conclusions of most of the previous studies that options trading have the effect of reducing the variability of stock prices (Skinner, 1990; Ho, 1993; Mendenhall and Fehrs, 1999; Easley, O'Hara and Srinivas, 1998, Truong and Corrado, 2014). The findings of this study do not agree with the school of thought that there is no significant relationship between options trading volumes and the fluctuation of stock prices, which is demonstrated in several studies (Whiteside et al., 1983; Klemkosky and Maness, 1980; Trennepohol and Dukes, 1979).

Option trading volumes are found to be negatively associated with the immediate stock prices response to earnings announcements and this finding supports the study of Truong and Corrado (2014), which found that the companies with higher option trading volumes tend to have smaller immediate stock price reactions to earnings announcements. However, as compared to the research of Truong and Corrado (2014), which found that call option trading volumes had the most significant explanations for stock price response to CAR, this research found that put option trading volumes had the most significant explanations for stock price response to CAR. The findings on the relevance of size in this research are in agreement with those of Truong and Corrado (2014); larger companies have a lower abnormal return response; but while Truong and Corrado (2014) find that the book-to-market ratio (BM) also has a significant positive effect, which by implication means value stocks (higher BM ratio) have a lower abnormal response, this study does not find the coefficient of the book to market ratio significant, though the coefficient has the same sign. The interaction of the earnings response coefficient on option trading volumes is also significant, meaning 
that the higher the element of surprise in earnings announcements, the greater the impact of interaction with option trading volumes, as found in previous studies.

The following explanations are offered for the differences in results: The method of computing stock price response to earnings announcements utilized in this study and in Truong and Corrado (2014) are different. While Truong and Corrado (2014) apply the buy-and-hold approach with abnormal returns computed with respect to the return of a similar size decile, this study uses a risk adjusted methodology for computing cumulative abnormal returns $(C A R)$, which is more appropriate. Secondly, there are substantial differences in the operating financial environment, in the pre-crisis period of 1996-2007, compared to the post-crisis period of 2010-2017: the VIX index and interest rates were higher in the pre-crisis period. Changes in the financial environment influence the behaviour of market participants and can explain why put options are more significant in the post crisis era compared to call options in the pre-crisis period.

\section{Conclusions}

This study investigated the impact of options trading volume on the immediate stock price response to earnings announcements of S\&P100 companies, in the immediate window $(-1$ to +1$)$ using a more appropriate method for ascertaining stock price responses than previous studies on this topic and the major findings are:

(1) higher option trading volumes have the effect of reducing the CAR (with different levels of significance for call and put option trading volumes) on S\&P100 stocks on earnings announcements (in the immediate window of $(-1$ to +1$)$ ) and this is a confirmation of the view that derivative securities have the effect of stabilizing prices in the market. Some previous studies held that option trading volumes had no effect or increased volatility in the underlying stock prices.

(2) the stock price response to earnings announcements was higher for smaller companies. This result is the same as a previous study in the pre-crisis period.

(3) relates to the impact of the surprise element in earnings announcements on the CAR and the interaction with option trading volumes. The surprise aspect alone is not significant but the interaction with option trading volumes is significant and most significant for put options. Its impact is that negative earnings surprises interacting with option trading volumes, reduce Value (CAR), while positive earnings surprises interacting with option trading volumes increased Value (CAR). This is a conclusive result for S\&P100 companies, over the window of this study.

(4) in the changed environment after the crisis, the choice of derivative instruments has changed from calls to puts. These points to the importance of perception of the financial environment by market participants in their choice of derivative instruments: calls are preferred when markets are perceived to be rising and puts are preferred when it is felt that markets may fall. The explanation is that in the aftermath of the crisis market participants are more cautious even though uncertainty (VIX index) is lower.

No other such study has been conducted in the post crisis period when the financial environment has changed and this research opens several opportunities for studying the behavior of users of derivative instruments in financial markets. This study thus contributes to the body of knowledge on the choices of derivative securities by market participants and the impact of option trading volumes and earnings surprises on stock price response while also drawing attention to the background financial environment.

\section{Limitations of this research and recommendations for the future}

This is a focused study on the choice of derivative instruments by market participants and the impact of option trading volumes and earnings surprises on stock price response while also drawing attention to the background financial environment. It is exploratory in nature and focuses only on S\&P 100 companies, with options traded on the CBOE. These are large stocks from various sectors and relatively more transparent. This study, however, throws up several areas for further research. Studies on different sectors, segments of the market can research whether market participant behaviour is similar or sector/segment specific. Future research can introduce additional variables into the models. Behavioural aspects play a large part in the day-to-day functioning of stock markets and this too can be modelled into the research to provide more insights on the functioning of markets in different financial environments. 


\section{References}

1. Ali, R. and Afzal, M. (2012). Impact of global financial crisis on stock markets: Evidence from Pakistan and India. E3 Journal of Business Management and Economics, 3 (7), 275-282.

2. AL-Shar, A.-K., Omar Zuhie, O. \& Dongfang, Q. (2017). Evaluations on the Earning Quality of Listed Firms in Jordan, International Journal of Academic Research in Accounting, Finance and Management Sciences, Human Resource Management Academic Research Society, International Journal of Academic Research in Accounting, Finance and Management Sciences, vol. 7(4), pages 21-32, October.

3. Amin, K.I. and Lee, C. (1997). Option trading, price discovery and earnings news dissemination. Contemporary Accounting Research, 14 (2), 53-192.

4. Amar, A. B., Chabchoub, M. (2016). Audit Quality and Earnings Management to Avoid Losses and Earnings Decreases: The French Case, International Journal of Academic Research in Accounting, Finance and Management Sciences, Human Resource Management Academic Research Society, International Journal of Academic Research in Accounting, Finance and Management Sciences, vol. 6(4), pages 20-27, October.

5. Asteriou, D. and Hall, S. G. (2015). Applied econometrics. Macmillan International Higher Education

6. Ball, R. and Kothari, S. P. (1991). Security returns around earnings announcements. Accounting Review, 66 (4), 718-738.

7. Bartram, S. M. and Bodnar, G. M. (2009). No place to hide: The global crisis in equity markets in 2008/2009. Journal of international Money and Finance, 28 (8), 1246-1292.

8. Bhattacharya, M. (1987). Price changes of related securities: The case of call options and stocks. Journal of Financial and Quantitative Analysis, 22 (1), 1-15.

9. Black, F. (1975). Fact and fantasy in the use of options. Financial Analysts Journal, 31 (4), 36-41.

10.Cao, C., Chen, Z., and Griffin, J. M. (2005). Informational content of option volume prior to takeovers. Journal of Business, 78 (3), 1072-1109.

11.CBOE (no date). Equity Option Volume. Chicago Board Options Exchange. Available from www.cboe.com/data/historical-options-data/equity-option-volume. [Accessed 08 September 2018].

12.CBOE (2014). CBOE Market Statistics 2014. Chicago Board Options Exchange. Available from www.cboe.com/data/marketstats-2014.pdf. [Accessed 08 September 2018].

13.Chiras, D. P. and Manaster, S. (1978). The information content of option prices and a test of market efficiency. Journal of Financial Economics, 6 (2/3), 213-234.

14.Choi, H. S. and Jayaraman, N. (2009). Is reversal of large stock-price declines caused by overreaction or information asymmetry: Evidence from stock and option markets. Journal of Futures Markets: Futures, Options, and Other Derivative Products, 29 (4), 348-376.

15.Conrad, J. (1989). The price effect of option introduction. The Journal of Finance, 44 (2), 487-498.

16.Cox, J. and Rubinstein, M. (1985). Options Markets, 1985. Options Markets, Englewood Cliffs.

17.Damodaran, A. and Lim, J., (1991). The effects of option listing on the underlying stocks' return processes. Journal of Banking \& Finance, 15 (3), 647-664.

18.Delong, B. J., Shleifer, A., Summers, L. H., and Waldmann, R. J. (1990). Noise Trader Risk in Financial Markets Source: The Journal of Political Economy, Vol. 98, No. 4, pp. 703-738.

19.Detemple, J. and Jorion, P. (1990). Option listing and stock returns: An empirical analysis. Journal of Banking \& Finance, 14 (4), 781-801.

20.Easley, D., O'hara, M. and Srinivas, P. S. (1998). Option volume and stock prices: Evidence on where informed traders trade. The Journal of Finance, 53 (2), 431-465.

21.FRED (2019). 3-Month Treasury Bill: Secondary Market Rate. FRED. Available from https://fred. stlouisfed.org/series/TB3MS. [Accessed 03 May 2019].

22.Gulec, T. C. (2016). Effects of Introduction of Options Market on Underlying Stock Market Volatility. The Case of Borsa Istanbul, Manisa Celal Bayar University, Conference Paper January 2016.

23. Ho, L. C. J. (1993). Option trading and the relation between price and earnings: A cross-sectional analysis. Accounting Review, 368-384.

24.Ho, L. C. J. and Liu, C. S. (1997). A re-examination of price behaviour surrounding option introduction. Quarterly Journal of Business and Economics, 39-50. 
25. Holowczak, R., Simaan, Y. E. and Wu, L. (2006). Price discovery in the US stock and stock options markets: A portfolio approach. Review of Derivatives Research, 9 (1), 37-65.

26. Hu, J., (2014). Does option trading convey stock price information?. Journal of Financial Economics, 111 (3), 625-645.

27.Hussin, B. M., Ahmed, A. D. and Ying, T. C. (2010). Semi-strong form efficiency: Market reaction to dividend and earnings announcements in Malaysian stock exchange. IUP Journal of Applied Finance, 16 (5), 36-60.

28.Investopedia (no date). Abnormal Return. Investopedia. Available from www.investopedia.com/ terms/a/abnormalreturn.asp. [Accessed 06 June 2018].

29. Investopedia (no date). Chicago Board Options Exchange - CBOE. Investopedia. Available from www.investopedia.com/terms/c/cboe.asp. [Accessed 08 September 2018].

30.Jelodari, A. and Fatemeh, A. K. (2016). A Survey of the Role of Earnings Quality in Accurately Forecasting of Operational and Cash Circulation of Companies Listed on Tehran Stock Exchange, International Journal of Academic Research in Accounting, Finance and Management Sciences, vol. 6, issue 4, 82-89.

31.Jennings, R. and Starks, L. (1986). Earnings announcements, stock price adjustment, and the existence of option markets. Journal of Finance, 41 (1), 107-126.

32.Joshi, H. (2018). Does Introduction of Stock Options Impact Stock Volatility? Empirical Evidence from Underlying Stocks in Indian Market, Theoretical Economics Letters, 2018, 8, 1803-1815.

33. Klemkosky, R. C. and Maness, T. S. (1980). The impact of options on the underlying securities. The Journal of Portfolio Management, 6 (2), 12-18.

34.Lim, S. (2009), Assessing the Effects of Earnings Surprise on Returns and Volatility with High Frequency Data, Duke University, Septemvber 2009, accessed at pubblic.econ.duke.edu/ get/browse/ courses/201/spr12/2010-PRESENTATIONS/FullECON202-FINAL_PAPERS/2009-December/Lim_Thesis.pdf,

35.Lin, T. C. and Lu, X. (2015). Why do options prices predict stock returns? Evidence from analyst tipping. Journal of Banking \& Finance, 52, 17-28.

36.Lobo, G. J., and Mahmoud, A. W. (1989). Relationship between differential amounts of prior information and security return variability. Journal of Accounting Research, 27 (1), 116-134.

37.Long, M., Schinski, M., Officer, D. (1994). The Impact of Option Listing on the Price Volatility and Trading Volume of Underlying OTC Stocks Journal of Economics and Finance! Volume 18, Number 1, Spring 1994, Pages 89-100.

38. MacKinlay, A. C. (1997). Event studies in economics and finance. Journal of Economic Literature, 35 (1), 13-39.

39. Manaster, S. and Rendleman, R. J. (1982). Option prices as predictors of equilibrium stock prices. Journal of Finance, 37 (4), 1043-1057.

40. Mayhew, S. and Mihov, V. (2000). Another look at option listing effects. Institute for Quantitative Research in Finance.

41. Mazouz, K., Wu, Y. and Yin, S. (2015). Trading Activity in Options and Stock around Price-Sensitive News Announcements. Journal of Futures Markets, 35 (12), 1173-1194.

42. Mendenhall, R. R. and Fehrs, D. H. (1999). Option listing and the stock-price response to earnings announcements. Journal of Accounting and Economics, 27 (1), 57-87.

43. Muravyev, D., Pearson, N. D. and Broussard, J. P. (2013). Is there price discovery in equity options?. Journal of Financial Economics, 107 (2), 259-283.

44.Pan, J. and Poteshman, A. (2006). The information in option volume for future stock prices. Review of Financial Studies, 19 (3), 871-908.

45.Patell, J. M. and Wolfson, M. A. (1979). Anticipated information releases reflected in call option prices. Journal of Accounting and Economics, 1 (2), 117-140.

46.Peterson, D. R. (1995). The influence of organized options trading on stock price behavior following large one-day stock price declines. Journal of Financial Research, 18 (1), 33-44.

47.Philbrick, D. R. and Stephan, J. A. (1993). Trading volume in options and common stock around quarterly earnings announcements. Review of Quantitative Finance and Accounting, 3 (1), 71-89. 
48. Roll, R., Schwartz, E., Subrahmanyam, A. (2009). Options trading activity and firm valuation. Journal of Financial Economics, 94 (3), 345-360.

49.Sakthivel, P., Veerakumar, K., Raghuram, G., Govindarajan, K. and Anand, V. V. (2014). Impact of global financial crisis on stock market volatility: Evidence from India. Asian Social Science, 10 (10), 86.

50.Sharpe, W. F. (1964). Capital asset prices: a theory of market equilibrium under conditions of risk. The Journal of Finance, 19 (3), 425-442.

51.Skinner, D. J. (1990). Options markets and the information content of accounting earnings releases. Journal of Accounting and Economics, 13 (3), 191-211.

52.Sorescu, S. M. (2000). The effect of options on stock prices: 1973 to 1995. The Journal of Finance, (1), 487-514.

53.Stein, J. (1989). Overreactions in the options market. The Journal of Finance, 44(4), 1011-1023.

54.Stephan, J. A. and Whaley, R. E. (1990). Intraday price changes and trading volume relations in the stock and stock option markets. Journal of Finance, 45 (1), 191-220.

55.Stulz, R. M. (2004). Should we fear derivatives?.Journal of Economic Perspectives, 18 (3), 173-192.

56.Syed, A. M. and Bajwa, I. A. (2018). Earnings announcements, stock price reaction and market efficiency-the case of Saudi Arabia. International Journal of Islamic and Middle Eastern Finance and Management.

57.S \& P Dow Jones Indices LLC (2018). S\&P Dow Jones Indices: A division of S\&P Global. S\&P 100 Dow Jones Indices LLC. Available from

http://us.spindices.com/idsenhancedfactsheet/file.pdf?calcFrequency=

M\&force_download=true\&hostldentifier=48190c8c-42c4-46af-8d1a-0cd5db894797\&indexld=243.

[Accessed 08 September 2018].

58.Trennepohl, G. L. and Dukes, W. P. (1979). CBOE options and stock volatility. Review of Financial Economics, 14 (3), 49.

59. Truong, C. and Corrado, C. (2014). Options trading volume and stock price response to earnings announcements. Review of Accounting Studies, 19 (1), 161-209.

60.Treasury (no date). Daily Treasury Bill Rates Data. U.S. Department of The Treasury. Available from https://www.treasury.gov/resource-center/data-chart-center/interest-rates/Pages/TextView.aspx?data= billRatesYear\&year=2009\&fbclid. [Accessed 08 September 2018].

61.Vijh, A. M. (1990). Liquidity of the CBOE equity options. Journal of Finance, 45(4), 1157-1179.

62.Whiteside, M.M., Dukes, W.P. and Dunne, P.M. (1983). Short term impact of option trading on underlying securities. Journal of Financial Research, 6 (4), 313-321.

63.S \& P Dow Jones Indices LLC (2018). S\&P Dow Jones Indices: A division of S\&P Global. S\&P 100 Dow Jones Indices LLC. Available from

http://us.spindices.com/idsenhancedfactsheet/file.pdf?calcFrequency=

M\&force_download=true\&hostldentifier=48190c8c-42c4-46af-8d1a-0cd5db894797\&indexId=243.

[Accessed 08 September 2018].

64.Yahoo! Finance (no date). S\&P 100 INDEX (^OEX). Yahoo! Finance. Available from https://uk.finance.yahoo.com/quote/\%5EOEX/history?ltr=1 [Accessed 03 May 2019].

65.Yahoo! Finance (no date). $\mathrm{CBOE}$ Volatility Index (^VIX). Yahoo! Finance. Available from https://finance.yahoo.com/quote/\%5EVIX/history/ [Accessed 03 May 2019]. 